\title{
Value Engineering for the Selection of the Filler Material between Shoring Wall and the Structure
}

\author{
Şenay ATABAY
}

\begin{abstract}
In the traditional construction projects, project shareholders develop their projects rather by taking the cost into consideration after the occurrence of the need. The companies should focus on quality, cost and speed in the projects they carry out to be able to keep up in the competitive environment. Value engineering is the revision of the new or existent products at the design stage for the purpose of increasing the value of the product, decreasing the cost and increasing the functionality. In this study, it has been tried to decide which material / method should be selected to be able to fill the space between a shoring wall and the structure with the use of Value Engineering Method. Firstly, a value engineering team has been formed; it has been decided which needs the material / method should meet, solutions that could provide these needs have been sought and it has been decided to compare three determined alternative solutions. Afterwards, value analysis has been conducted and the solution that can meet the need both in terms of quality and cost has been tried to be selected. In this way, economically most convenient solution has been determined without neglecting the requests of the customers and the benefit to be attained. As a result of the Value Engineering study, it was concluded that Alternative $2 \mathrm{~b}$ (making waste mold with profile and $15 \mathrm{~mm}$ oriented strand board) is the most suitable solution.
\end{abstract}

Keywords: construction management; geotechnical engineering; selection of material; shoring wall; value analysis; value management

\section{INTRODUCTION}

Construction sector is one of the most important sectors for all countries. The fact that the construction projects may be affected by the long-term, complex, economic and social developments requires the performance of systematic studies so as not to have undesired results. Successful completion of the projects and minimization of losses have great importance both for the companies and the state economy.

Three main problems faced by the operations in construction sector are quality, cost and time [1]. Today's economic conditions have obligated the performance of the cost control within the period of time starting from the first stage of the design to the completion of the project. Any modifications conducted in the construction stage after the completion of the design will substantially affect the project cost and period [2]. Therefore good inspection of the project during the design stage and consideration of all possible alternatives is important in terms of attaining the optimum cost. Administration and cost techniques increasing day by day are used altogether. Value engineering (VE) is the main of the techniques applied to decrease the cost and ensure the priority in the market competition.

In this article, a Value Engineering study has been conducted for the selection of the filling material to be used in the space between the shoring wall and the structure. Usually, very large amounts of material must be used in this area. In this case, the most appropriate behaviour is to find the lowest cost solution under certain constraints. Value engineering is one of the very important methods to reach this solution.

A comprehensive literature search has been done and in the literature review there is no study on the subject similar to this article.

\section{LITERATURE REVIEW}

There are many studies conducted using Value Engineering Method regarding the selection of constructing materials. Mousakhaniet.al. 's study aims to present a practical model for the implementation and application of value engineering process in a construction project located in a special region (in terms of tourism, positioning in an economic growth path, and the East-West strategic axis of the region) [3]. Li et. al.'s study investigated the relationship between cost and performance of slope erosion control products in the Texas Department of Transportation's Approved Products List [4]. Sivakumar Babu et. al.'s paper reports a case study of stabilising a vertical cut supporting a masonry retaining wall in hilly terrain, which is being developed with considerable investment and infrastructure [5]. Katzenbach et al. say that Value Engineering can be applied for any type of geotechnical structures like foundation systems, deep excavations, slopes, dams and tunnels, and explain the principle of Value Engineering and present its application in engineering practice [6]. Shahhasseini at. al.'s study is about water supply to Ilam Gas Refinery. A thoroughly systematic VE study proved it possible not only to save as much as $41 \%$ in the overall costs of the construction work, but also reducing environmental damages to one-fifth by adapting a different alternative track to cross the Reno Mountain [7]. The aim of Lee's study is the development of the corresponding decision-making process for the selection of façade materials to minimize the potential defects at the design stage. The case study reveals that the priority of the material options for building façade can be changed if minimum $30 \%$ weighting of the durability for each option is reflected on the decision-making process [8]. Khodeir and Ghandour's paper's main objective is to examine the role of Value Management in controlling cost overrun, with special reference to residential projects in Egypt [9]. In Giménez et. al.'s paper, a value analysis model (VAM) is proposed to measure the value creation expected by customers and to identify value losses through indexes. As points of reference, the model takes the Kano model and target costing, which is used in the building project design process [10]. Wei and Chen's paper takes residential buildings as an example, and uses BIM simulation technology combined with value engineering to 
analyze the relationship between cost and energy saving in the architectural design process [11]. In Mahmoud and Deab's study, based on value engineering principles and a carbon dioxide emissions calculator, the approach was applied to three case studies: temporary retaining walls for a deep tunnel; reuse of site-won material from an open-cut tunnel; and design of piled-raft foundations. The results showed the approach was effective in reducing carbon dioxide emissions and could be beneficially adopted on future earthworks projects in the Middle East [11].

\section{VALUE ENGINEERING METHOD}

Value engineering can be defined as the process of relating the functions, the quality, and the costs of the project in determination of optimum solutions for the project [13]. The procedures of value engineering lead to a solution that emphasizes the role of the functions of the project, seeks to achieve whole-life value for the project, and relies on the best judgment of the study team in making final design choices [14]. Value Engineering is the technique of producing cost-decreasing ideas conducted by focusing on the functions of a product without making any concessions to the properties desired by the customers and elongating the development process of the product. It is examined by analyzing the functions whether the product or service has provided the desired quality level and also whether it is convenient for the expectations of the customer. If required, the functions considered as not needed as a result of the function analysis could be excluded from the process or new functions could be added for the purpose of meeting the expectations of the customer. The value being the scale of the customer choice is actually a phenomenon becoming certain as a result of the quality of the product. A product or service designed and produced in accordance with the expectations is found valuable by the customer and it is qualified [15].

It is seen that the history of the Value Engineering dates back to the periods of the World War II. In 1940s in which the USA production had scarce resources, General Electric Company showed a programmed survey team based approach for the attainment of the best value with the leadership of Purchasing Manager Lawrens Miles. Lawrence D. Miles worked as the official application responsible for this technique from 1947 to 1952 [16]. In 1952, this method started to be applied in all 82 factories of General Electric Company in the USA. Its benefit was observed in the next periods and its usage became common all over the world.

The purpose of VE could be given as follows [17]:

$>$ Preventing the unnecessary cost.

$>$ Using the existent money, material and human resources in a productive and efficient way.

$>$ Decreasing the construction period by using the time efficiently.

$>$ Increasing the quality.

$>$ Providing construction safety.

$>$ Providing long-lasting construction.

$>$ Revealing the personnel skills via the psychological techniques such as team work, creativity and adaptation.

$>$ Adding the necessary (valuable) functions in the process and excluding the unnecessary (valueless) ones from the process by detecting the functions valuable and valueless for the customer.

In recent years, many publications on value engineering have been prepared. Tohidi has proposed the expression of different techniques used in value engineering with different phases of expression during the life of IT projects, using techniques based on the proposals presented [18]. Berawi's study is aimed at improving the feasibility of project investment for the conceptual design of Jakarta-Surabaya HST project by using Value Engineering [19]. In Behncke's study, the original model for Integrated Value Engineering was applied on industrial use cases of industrial gas engines for power generation and thereby provided enough details for the deduction of initial potentials for improvement [20]. Park's study developed a BIM-based Value Engineering Idea bank to efficiently reuse and retrieve past VE ideas and effectively generate new alternatives and VE ideas [21]. Lee has prepared a study on the building façade using Value Engineering [22]. The aim of this study is therefore the development of the corresponding decision-making process for the selection of façade materials to minimize the potential defects at the design stage. Sudiarsa's study aims to obtain cost savings made during the design phase and irrigation drainage project implementation [23].

\subsection{Functional Analyses}

The complete function of the product should be taken into consideration at the beginning and other parts and sections should not be examined to be able to conduct a functional assessment in value engineering. The purpose is to fulfil the same function with the lowest cost and with the same quality and reliability [24].

Functional analysis (assessment) seeks the answers to the following questions [25]:

$>$ What is it for?

$>$ What is it?

$>$ How much does it cost?

$>$ What is the value of the provided main function?

$>$ How is the main function provided alternatively?

$>$ What is the cost of the alternative?

The decided alternatives are assessed in terms of cost. Assessment could be successfully finalized with the following methods:

$>$ Comparison to a standard providing similar function.

$>$ Comparison to a product with similar physical appearance.

$>$ Comparison to a product with similar processes during the production.

$>$ Dividing into basic functional areas as much as being able to be compared to the commercial products fulfilling similar functions.

$>$ Specifying the amount and cost of the material necessary for performing the function.

$>$ Demolishing, creating and excellence.

$>$ Firstly realizing the creative thinking and determining the costs for the ideas.

\subsection{Value Calculation}

The value of a product in value engineering could be formulized in the following ways [26]: 
Value $=$ Deserts $/$ Cost

Value $=$ Customer Satisfaction $/$ Cost

Value $=($ First Impact of User +

+ Benefit from the goods $) /($ First Cost +

+ Following Pricing)

Value $=$ Functionality $/$ Cost

The values of the products, processes and/or services are determined and Value Analysis is conducted for each alternative during and after the functional assessment. The alternative whose value is high is determined as the applicable and usable product, process/service.

\section{CASE STUDY FOR VALUE ENGINEERING}

In this study, the application of value engineering for the selection of the filler material to be used in the space between the shoring wall and the structure is done.

The elevation of $-12.30 \mathrm{~m}$ had to be descended for a high-rise construction project carried out in an intensive settlement unit in Istanbul. The need for the construction of shoring system occurred for the purpose of preventing the slide of the ground/soil in the surroundings of the basement floors and foundation excavation. In Fig. 1, bored piles, upper chord beams, waler beams, anchor ropes and anchor plates are seen in the excavation area in which shoring application is conducted.

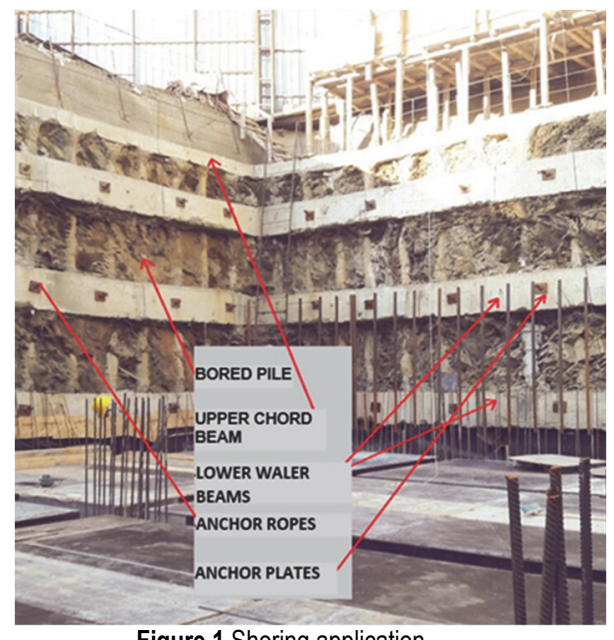

Figure 1 Shoring application

\subsection{Need for the Performance of Value Engineering}

Today, the obligation of constructing high-rise buildings occurs due to the increases in the values of the fields in great metropolis such as Istanbul and this situation increases the need for making deep excavation in the projects. In this process as different from the aboveground, new and additional problems are seen in the underground constructions. While the buildings to be constructed under-ground are expected to meet all security conditions, also the expectation for them to be economical has importance in terms of engineering. In this process, the need for filling the space remaining between the shoring construction and the building in an economical way has occurred on condition that it will provide the determined quality properties. This problem has required the project team to conduct Value Engineering work regarding the issue.

In the project the shoring work has been completed in the field excavation conducted at the depth of $-12.30 \mathrm{~m}$ from the ground surface to the lower elevation of the foundation and the reinforced concrete productions will be started. Piles have been driven with the bored pile method out of the external contour of the building (within the parcel) for not causing any loss of area in the building in the shoring application and the driven piles have been connected to one another with waler beams with an interval of $1.5 \mathrm{~m}$ as top down. The external curtains of the building will be leaned on the piles up to the soil elevation and the space remaining between the shoring construction and the building will be filled with a material. Value-based selection of method to be applied during filling this space and the filler material constitutes the subject of the study. The plan of the shoring system and the foundation plan are seen in Fig. 2.

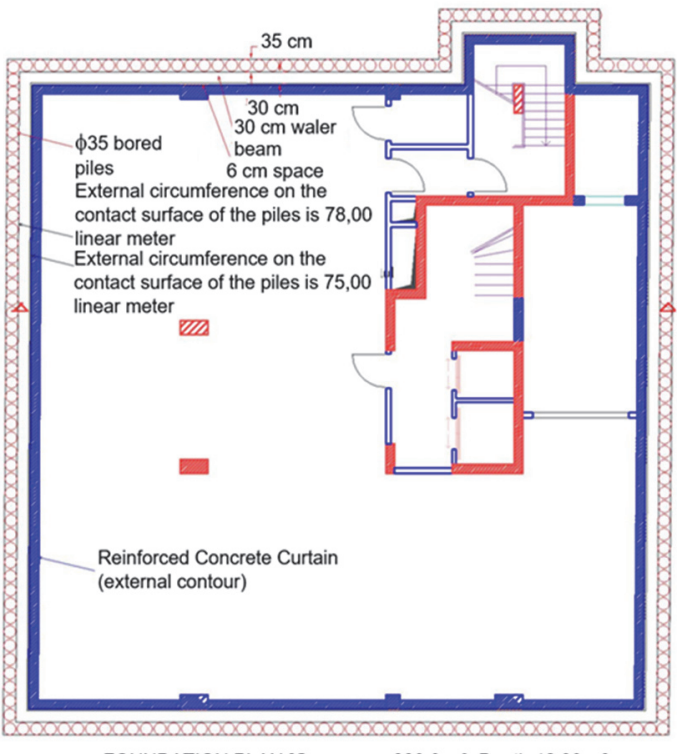

FOUNDATION PLAN [Gross area $330,0 \mathrm{~m}^{2}$, Depth $1230 \mathrm{~m}$ ] Figure 2 Plan of the shoring system and foundation

\subsection{Determination of the Qualifications}

In this project, stages of the Value Engineering Work Plan have been applied step by step. Value Engineering Team has brainstormed in the issue of which qualifications the method they consider to apply should provide after the determination of the problem. It has been decided that the method to be applied or the material to be used should provide the following conditions:

$>$ Applicability in short-term.

$>$ Usage of minimum stock area.

$>$ Low cost.

\subsection{Determined Alternative Methods}

The methods/materials that could provide and apply the aforementioned qualifications have been determined again by the value engineering team as a result of experience and conducted studies. The alternatives determined by the team are as follows: 
- $\quad 1^{\text {st }}$ Alternative: Pouring concrete filler; Allowing the filling of the concrete also between the waler beams and pouring concrete up to the pile surface.

In this situation, excessive concrete will be poured and the cost will increase, but it will not cause any additional work and time costs in the project.

- $\quad 2^{\text {nd }}$ Alternative: Closing the waler beam spacings with material; closing the spaces remaining between the waler beams with a determined material and constructing the building external curtains within the correct dimensions.

In this situation, excessive concrete cost will be terminated, but new costs will occur regarding this work due to the fact that a new work item has been opened. It is also expected that the selected method will bring additional time to the project as well as bringing a new work load.

\subsection{Cost Analyses of the Alternative Methods 4.4.1 Alternative 1}

Allowing the filling of the concrete also between the waler beams during the preparation of the reinforced concrete curtains and pouring concrete up to the pile surface:

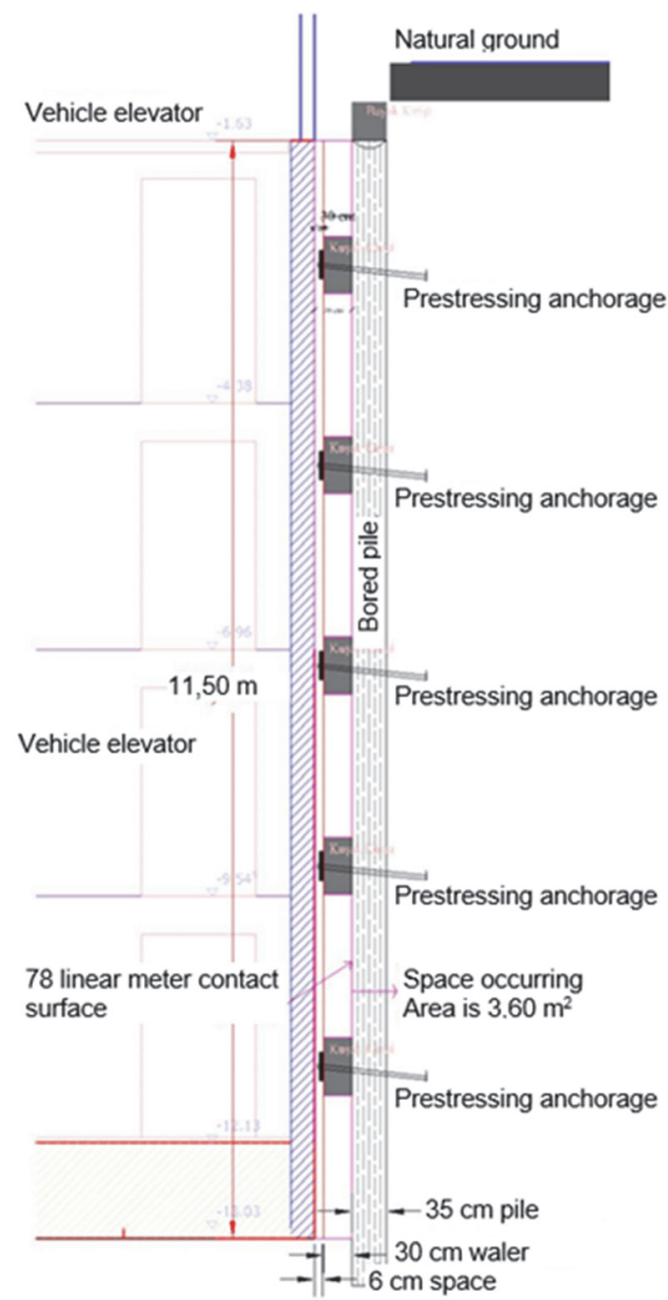

Figure 3 Area to which additional concrete will be poured

The section of the area remaining between the building contour and piles is $3.60 \mathrm{~m}^{2}$ (Fig. 3). There is a pile contact surface of 78 linear meters.

Here:
It means that $78.00 \mathrm{~m} \times 3.60 \mathrm{~m}^{2}=280.80 \mathrm{~m}^{3}$ additional concrete will be used.

The price of $1 \mathrm{~m}^{3}$ ready-mixed concrete is 195.00 $\mathrm{TL} / \mathrm{m}^{3}$ for $\mathrm{C} 35 / 45$ [27]. (It is a value showing differences depending on the project and it is the unit price of the concrete purchased in the period in which the application has been performed.)

Cost of the excessively poured concrete is: $281 \mathrm{~m}^{3} \times 195.00 \mathrm{TL} / \mathrm{m}^{3}=54.795,00 \mathrm{TL}$

Table 1 Advantages and disadvantages of the alternative 1

\begin{tabular}{|l|r|}
\hline Advantages of the Alternative 1 & Disadvantages of the Alternative 1 \\
\hline$>$ Only the depth of the curtain \\
concretes which would \\
already be poured has \\
increased and this situation \\
does not cause any additional \\
time increase in the project. \\
No problem affecting the \\
determined completion period \\
of the work will occur.
\end{tabular}

\subsubsection{Alternative 2}

Closing the waler beam spacings with a material to be selected and constructing the building external curtains within the correct dimensions:

Two different sub-alternatives have been determined by the Value Engineering Team for Alternative 2. These are:

a) Closing the spaces by bonding wall.

b) Making waste mold with profile and $15 \mathrm{~mm}$ OSB2 (oriented strand board).

Cost Analysis for Alternative 2a: Closing the spaces by bonding wall (Fig. 4).

Spaces could be closed by bonding wall. Brick and gas concrete may not meet the side loads to be formed by the fresh concrete due to the fact that they are weak in terms of strength. For this reason Value Engineering Team has assessed $20 \mathrm{~cm}$ masonry brick and $15 \mathrm{~cm}$ pumice which are safer than brick or gas concrete in terms of the bearing power, but which are not so different in terms of security when compared to one another in terms of their costs and has decided to select one of them.

Masonry brick $(29 \times 13.5 \times 19)$ material unit $\mathrm{m}^{2}$ cost is: $\left(1 \mathrm{~m}^{2} /(0.29 \times 0.135)\right) \times(0,65 \mathrm{TL} / \mathrm{pc})=.16.60 \mathrm{TL} / \mathrm{m}^{2}$.

$15 \mathrm{~cm}$ pumice $(33 \times 25 \times 15)$ material unit $\mathrm{m}^{2}$ cost is: $\left(1 \mathrm{~m}^{2} /(0.33 \times 0.25)\right) \times(0.54 \mathrm{TL} / \mathrm{pc})=.6.55 \mathrm{TL} / \mathrm{m} 2$.

In this situation it has been decided that $15 \mathrm{~cm}$ pumice with lower cost will be used as Alternative $2 \mathrm{a}$.

Wall calculation: $(11.50-(5 \times 0.60)) \times 75 \mathrm{~m}=637.5$ $\mathrm{m}^{2}$ wall production will be conducted.

Mortar cost for $1 \mathrm{~m}^{2}$ wall is: $0.015 \mathrm{~m}^{3} / \mathrm{m}^{2} \times 200.00$ $\mathrm{TL} / \mathrm{m}^{3}=3 \mathrm{TL} / \mathrm{m}^{2}$.

Lump sum price wall labor cost price is: $12.5 \mathrm{TL} / \mathrm{m}^{2}$.

Total unit wall cost is: $22.00 \mathrm{TL} / \mathrm{m}^{2}$.

Wall cost is (Mat. + Labor Cost) $637.50 \mathrm{~m}^{2} \times 22 \mathrm{TL} / \mathrm{m}^{2}$ $=14,025 \mathrm{TL}$.

Shipments, in-site handling, expense costs etc. are approximately $975.00 \mathrm{TL}$.

Additional cost of concrete to be used for the remaining $6 \mathrm{~cm}$ is: $78 \mathrm{~m} \times 0.06 \mathrm{~m} \times 11.50 \mathrm{~m} \times 195.00$ $\mathrm{TL} / \mathrm{m}^{3}=10.500,00 \mathrm{TL}$.

Total Wall Bonding Work Cost is found as 25.500,00 TL. 


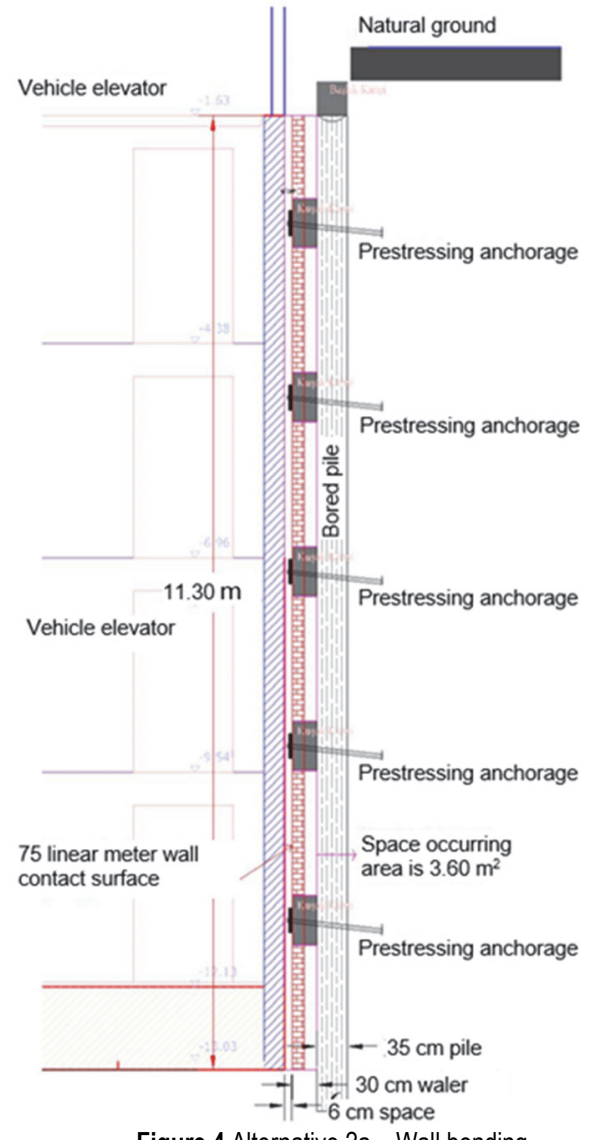

Figure 4 Alternative $2 a-$ Wall bonding

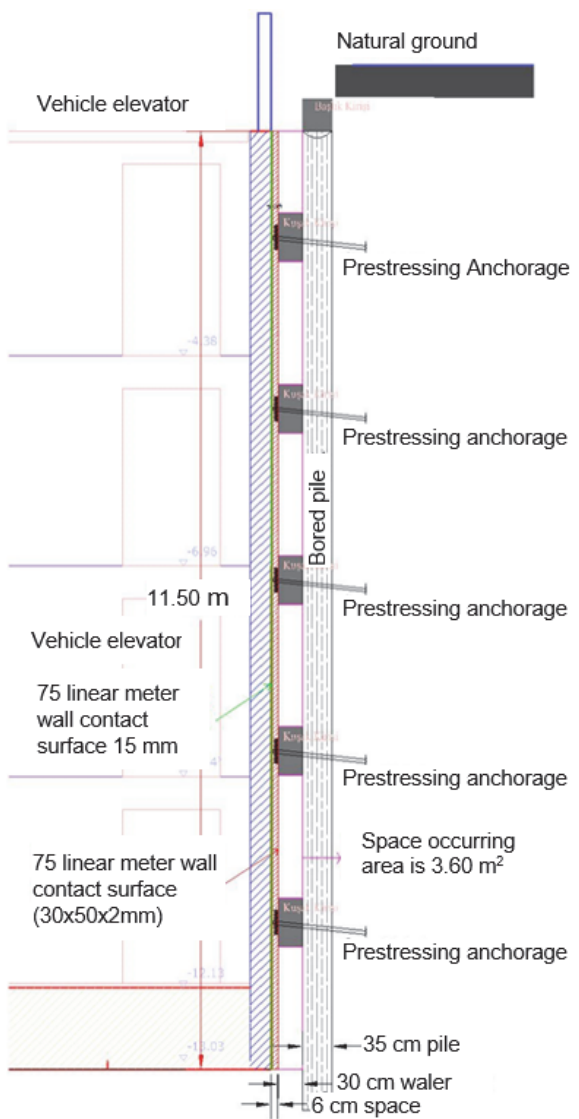

Figure 5 Making waste mold with profile and $15 \mathrm{~mm}$ OSB2

Table 2 Advantages and disadvantages of alternative $2 a$

\begin{tabular}{|c|c|}
\hline Advantages of Alternative $2 \mathrm{a}$ & Disadvantages of Alternative $2 \mathrm{a}$ \\
\hline $\begin{array}{l}\text { Same function could be fulfilled by } \\
\text { bonding wall instead of undergoing the } \\
\text { cost of TL } 54.795,00 \text { in the complete } \\
\text { concrete pouring. } \\
\text { Employment will be provided to the } \\
\text { masons. } \\
\text { Wall will come to the desired strength } \\
\text { during the iron and mold productions } \\
\text { which will continue after the wall. }\end{array}$ & $\begin{array}{l}\text { Wall bonding work will be conducted right after the concrete pouring for each floor. Stock area which will } \\
\text { keep ready the materials of pumice }+ \text { sand }+ \text { cement in the construction site will not be available at the } \\
\text { moment of rough construction. It will cause extra shipments for the materials purchased part by part. } \\
\text { Fulfillment of this function by bonding wall may cause loss of time. Approximately } 160 \mathrm{~m}^{2} \text { wall will be } \\
\text { bonded in each floor and half of them will be bonded upon the scaffold. Upon the assumption that maximum } \\
\text { wall amount that could be completed by } 1 \text { person is } 20 \mathrm{~m}^{2} / \text { day, } 160 / 20=8 \text { masons will be needed. When the } \\
\text { site conditions are taken into consideration, this work will be completed in } 2 \text { days in all likelihood, but it will } \\
\text { normally be completed in } 3 \text { days. This will cause the iron and mold works to be postponed by } 1 \text { or } 2 \text { days in } \\
\text { each floor. }\end{array}$ \\
\hline
\end{tabular}

Table 3 Advantages and disadvantages of alternative $2 \mathrm{~b}$

\begin{tabular}{|c|c|}
\hline Advantages of Alternative $2 b$ & Disadvantages of Alternative $2 b$ \\
\hline $\begin{array}{l}\text { Same function could be fulfilled by bonding wall instead of undergoing the cost of TL } 54.795,00 \text { in the } \\
\text { complete concrete pouring. } \\
\text { Employment will be provided to the masons. } \\
\text { The filler material could be purchased as } 28.500,00 \text { TL by forming vertical ground with the profile and } \\
\text { with OSB screwing method on it instead of the cost of TL } 54.795,00 \text { spent on complete concrete pouring. } \\
\text { Employment will be provided to the welding team. } \\
\text { Reinforcement laborship will be performed more decently because there is a smooth surface behind it. } \\
\text { The work is a practical one. Profile irons will be cut with the length of } 3 \text { linear meters in } 3 \text { floors with the } \\
\text { interval of } 61 \mathrm{~cm} \text {, will be fixed vertically in its scale, OSBs will be practically screwed on them and the } \\
\text { production will be completed. } \\
\text { Welding and screwing work is a work which will finish in } 1 \text { day with } 3 \text { craftsmen and } 1 \text { assistant for each } \\
\text { floor. } \\
\text { It does not occupy any space in the construction site at the stock condition, it is not a rough material. } \\
\text { Ironsmith team will make preparations to bond the reinforcements (cutting the distributions, preparation } \\
\text { of the stirrups, preparation of the longitudinal reinforcements and bringing them to the assembly place) } \\
\text { and the welding team will give work to the ironsmith before starting the assembly. In this way, both } \\
\text { welding team and the ironsmith team will be able to be working at the same time in the site. }\end{array}$ & $\begin{array}{l}\text { Extra shipments may occur if the } \\
\text { materials are purchased separately for } \\
\text { each floor. }\end{array}$ \\
\hline
\end{tabular}

Cost Analysis for Alternative 2b: Making waste mold with profile and $15 \mathrm{~mm}$ OSB2 (Fig. 5).

Box Profile Calculation:
By taking the inertia moment into consideration, it has been detected that the most convenient profile which could be used for $6 \mathrm{~cm}$ space is $30 \times 50 \times 2 \mathrm{~mm}$ box profile. 
It has been determined that the box profile should be used at $75.00 \mathrm{~m}$ horizontal distance with the interval of 61 $\mathrm{cm}(\mathrm{OSB}-122 \times 244)$. In this situation, a total of 124 profiles are needed.

Box profile material: 124 ea. $\times 11.50 \mathrm{~m} \times 2.07 \mathrm{~kg} / \mathrm{m}=$ $2.950 \mathrm{~kg}$.

OSB2 Calculation: $75.00 \mathrm{~m} \times 11.50=862.5 \mathrm{~m}^{2}$

The reason why OSB2 is preferred is that it is cheaper and fulfills the same function when compared to OSB3, there is no need for it to be resistant for a long time, the price of OSB2 is approximately $16 \mathrm{TL} / \mathrm{m}^{2}$ at the period in which the application has been conducted and it is cheaper than OSB3.

Material costs:

OSB2: $862.5 \mathrm{~m}^{2} \times 16 \mathrm{TL} / \mathrm{m}^{2}=13.800,00 \mathrm{TL}$

Box Profile: $2950 \mathrm{~kg} \times 2.40 \mathrm{TL} / \mathrm{kg}=7.080,00 \mathrm{TL}$.

Labor costs:

OSB2: $862.50 \mathrm{~m}^{2} \times 2.00 \mathrm{TL} / \mathrm{m}^{2}=1.725,00 \mathrm{TL}$ (will be screwed to the ready surface).

Box Profile:

$2950 \mathrm{~kg} \times 2.00 \mathrm{TL} / \mathrm{kg}=\mathrm{TL} 5.900,00 \mathrm{TL}$ (will be welded on the waler surface).

Total Cost: $28.505,00 \mathrm{TL}$

\subsection{Importance Order and Percentages of the Qualifications}

The Priority Matrix shown in Tab. 4 has been formed as a result of the assessment conducted by Value Engineering Team.

Table 4 Importance orders and percentages of the qualifications with priority matrix

\begin{tabular}{|l|c|c|c|c|c|}
\hline & $\begin{array}{c}\text { Applicabili } \\
\text { ty in short- } \\
\text { term }\end{array}$ & $\begin{array}{c}\text { Usage of } \\
\text { minimum } \\
\text { stock area }\end{array}$ & Total & $\%$ & $\begin{array}{c}\text { Sequence } \\
\text { No }\end{array}$ \\
\hline $\begin{array}{l}\text { Applicability in } \\
\text { short-term }\end{array}$ & 1 & $1+1$ & 66.6 & 1 \\
\hline $\begin{array}{l}\text { Usage of minimum } \\
\text { stock area }\end{array}$ & 0 & & $0+1$ & 33.3 & 2 \\
\hline & & & 3 & 100 & \\
\hline
\end{tabular}

\subsection{Determination of the Satisfaction Levels of the Alternatives}

Satisfaction levels have been determined for the applicability in short-term in Tab. 5 and for the stock area usage qualification values in Tab. 6. It has been assumed that the satisfaction level for the most negative quality status is 1 and the satisfaction level for the most positive quality status is 10 and the intermediate values have been found with the help of Benefit Curve.

Table 5 Satisfaction levels for the quality value of applicability in short-term

\begin{tabular}{|c|c|c|c|}
\hline Qualifications & Alternative 1 & $\begin{array}{c}\text { Alternative } \\
2 \mathrm{a}\end{array}$ & $\begin{array}{c}\text { Alternative } \\
2 \mathrm{~b}\end{array}$ \\
\hline Applicability in short-term & 2 Day & $4-8$ Day & 3 Day \\
\hline Satisfaction Level & 10 & 1 & 7.5 \\
\hline
\end{tabular}

Table 6 Satisfaction levels for the quality value of stock area usage

\begin{tabular}{|l|c|c|c|}
\hline \multicolumn{1}{|c|}{ Qualifications } & Alternative 1 & Alternative 2a & Alternative 2b \\
\hline $\begin{array}{l}\text { Usage of minimum } \\
\text { stock area }\end{array}$ & $20 \mathrm{~m}^{2}$ & $50 \mathrm{~m}^{2}$ & $30 \mathrm{~m}^{2}$ \\
\hline Satisfaction Level & 10 & 1 & 7 \\
\hline
\end{tabular}

\subsection{Value Calculation of the Alternatives}

The purpose in Value Engineering is the selection of not the method or material with the lowest cost, but with the highest value. Therefore in this study, the values of the alternative methods will be calculated.

Value is calculated with the formula of:

$$
\frac{\text { Convenience for Usage(Utility) }}{\text { Cost }}
$$

Convenience for Usage (Benefit) is determined with the following equation:

Convenience for Usage = Importance $x$ Satisfaction Level

Quality / Function Matrix has been benefitted to calculate the benefits of each alternative solution and quality (function) (Tab. 7). The importance of the alternatives has been found by distributing the previously determined importance levels of each quality by the ratio of the materials to meet the performance of that quality.

\begin{tabular}{|c|c|c|c|c|}
\hline & & $\begin{array}{l}\text { Applicability } \\
\text { in short-term }\end{array}$ & $\begin{array}{l}\text { Usage of } \\
\text { minimum } \\
\text { stock area }\end{array}$ & Total \\
\hline \multirow{3}{*}{$\begin{array}{l}\text { Alternative } \\
1\end{array}$} & Importance & 22.2 & 11.1 & 33.3 \\
\hline & Satisfaction Level & 10 & 10 & 20 \\
\hline & Benefit & 222 & 111 & 333 \\
\hline \multirow{3}{*}{$\begin{array}{l}\text { Alternative } \\
2 \mathrm{a}\end{array}$} & Importance & 22.2 & 11.1 & 33.3 \\
\hline & Satisfaction Level & 1 & 1 & 2 \\
\hline & Benefit & 22.2 & 11.1 & 33.3 \\
\hline \multirow{3}{*}{$\begin{array}{l}\text { Alternative } \\
2 \mathrm{~b}\end{array}$} & Importance & 22.2 & 11.1 & 33.3 \\
\hline & Satisfaction Level & 7.5 & 7 & 14.5 \\
\hline & Benefit & 166.5 & 77.7 & 244.2 \\
\hline
\end{tabular}

In Tab. 8 , benefit values of each alternative have been divided into their costs and their values have been calculated.

Table 8 Value calculation

\begin{tabular}{|l|c|c|c|}
\hline & Alternative 1 & Alternative 2a & Alternative 2b \\
\hline Benefit & 333 & 33.3 & 244.2 \\
\hline Cost & $54.795,00$ & $25.500,00$ & $28.505,00$ \\
\hline Value & 0.006077197 & 0.001305882 & 0.008566918 \\
\hline
\end{tabular}

In Tab. 9, the analyses of the alternative solutions have been conducted and the method to be used in the application has been tried to be decided.

\subsection{Selection of the Most Convenient One among the Alternative Solutions}

Bonding wall is not preferred although its cost is the least. Its value ratio is very low and it causes the extension of the project time. Alternative $2 b$ which, having the highest value ratio, is preferred for the application. It is an application with medium cost, but with high value ratio.

The applied status of the method is seen in Fig. 6 . During the application a smooth surface has been attained 
with the box profiles in front of the waler beams, OSBs have been screwed on the profile surface, waste mold surface has been formed behind the mold and afterwards, reinforcement + mold works have been completed and concretes have been poured.

Table 9 Value analysis for the curtain alternatives in under-ground structures

\begin{tabular}{|c|c|c|c|c|c|c|}
\hline \multicolumn{2}{|c|}{ Suggestions for application } & \multirow{2}{*}{$\begin{array}{c}\text { Explanation of the } \\
\text { suggestion } \\
\begin{array}{c}\text { Filling all spaces with } \\
\text { concrete }\end{array} \\
\end{array}$} & \multirow{2}{*}{$\begin{array}{l}\text { Does it meet } \\
\text { the expected } \\
\text { function? } \\
\text { Yes }\end{array}$} & \multirow{2}{*}{$\begin{array}{l}\text { Cost necessary to } \\
\text { be undergone } \\
\text { TL } 54.795,00\end{array}$} & \multirow{2}{*}{$\begin{array}{c}\text { Value }=\text { Benefit/Cost } \\
0.0061\end{array}$} & \multirow{2}{*}{$\begin{array}{c}\text { How does it affect the } \\
\text { project period? } \\
\text { Project is continuing } \\
\text { within its normal period. }\end{array}$} \\
\hline Alternative 1 & Pouring concrete & & & & & \\
\hline \multirow[b]{2}{*}{ Alternative 2} & a) Bonding wall & $\begin{array}{l}\text { Closing the spaces by } \\
\text { bonding wall with pumice }\end{array}$ & Yes & TL 25.500,00 & 0.0013 & $\begin{array}{l}\text { Project productions delay } \\
\text { between } 4 \text { - } 8 \text { days. }\end{array}$ \\
\hline & $\begin{array}{l}\text { b) Making waste } \\
\text { mold }\end{array}$ & $\begin{array}{c}\text { Forming carcass with the } \\
\text { box profile and forming a } \\
\text { closed surface by screwing } \\
\text { OSB on it }\end{array}$ & Yes & TL 28.505,00 & 0.0085 & $\begin{array}{l}\text { Project is continuing } \\
\text { within its normal period. }\end{array}$ \\
\hline
\end{tabular}

This conducted waste mold application is permanent after this moment. It will remain under the ground after the backfilling is conducted. Even if it decays under the ground after a while, it will not be able to have any negative impact on the construction. The floorings of the floor whose reinforced concrete curtains and columns have been completed have also been produced as leaning on the constructed waste molds.

An additional benefit of this application has been the fact that the spaces remaining between the waler beams and the building curtain have protected the construction against water by working as drainage. The waters leaking under the ground could easily reach the drainage pipes existent under the foundation thanks to these spaces.

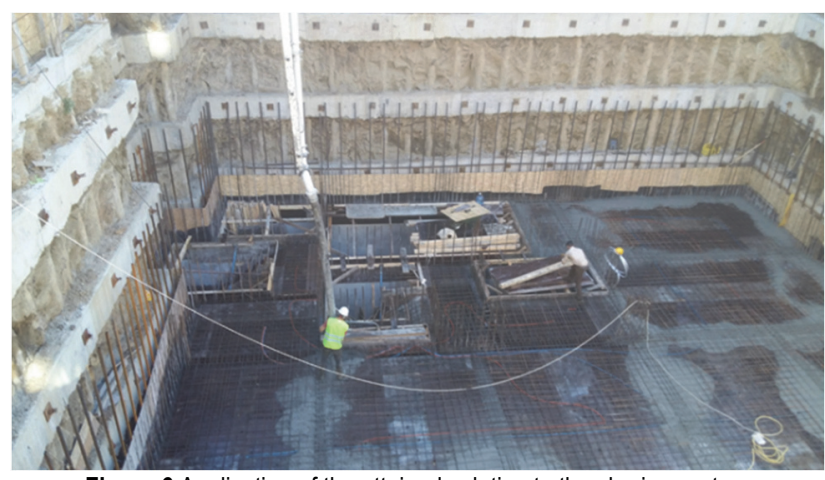

Figure 6 Application of the attained solution to the shoring system

\section{CONCLUSION}

Value engineering is a technique that not only takes the cost as the basis, but could also produce value-based solutions among the alternatives that could fulfill the customer demands and project requirements.

Because the solution of the problem is sought via a team consisting of many people, the problem is approached with different points of view and it is handled in a wide frame. Value engineering team formed by the shareholders with technical knowledge and capacity suggests various alternatives and ideas by working for a certain period of time at the stage of project design. Value analysis, function analysis and target costing works are conducted on these alternatives and the alternative or alternatives with the highest value index are presented to the employer and the team that will carry out the design. Permanent changes are definitely made on the project design after a successful value engineering work. For this reason both the customer and the contractor company make profit at the end of the value engineering works. While a method that has not been tried before could sometimes be the solution to the problem, a method applied in a very different area could sometimes be used as a solution with adaptations convenient for the structure of the problem.

In this study, it has been tried to decide which material/method should be selected so as to fill the space between a shoring wall and the structure with the use of Value Engineering Method. There could be many products that could fill this space or a method could be applied in the market. Which one of these products or methods will be selected for usage is generally determined by a costbased study; but, this is not a correct behaviour all the time. The determined product is to be the product/method which could meet the customer demands or the determined qualifications and the one that has the lowest cost; in other words, which is valuable will be a much more convenient selection criterion. With this purpose firstly a value engineering team has been formed and the qualifications necessary to be provided by the products or methods that could be the solution of the problem and the importance percentages and priority orders of these qualifications have been determined by this team. Solutions that could provide these qualifications have been sought and it has been decided to compare three alternative solutions in terms of value. The satisfaction levels and the ratios of these products for meeting the qualifications have been determined and afterwards, value analysis has been conducted and a product that could respond to the needs both in terms of quality and cost has been selected among these products.

Recommended $1^{\text {st }}$ alternative is allowing the filling of the concrete also between the waler beams during the preparation of the reinforced concrete curtains and pouring concrete up to the pile surface. This situation does not cause any additional time increase in the project but extra concrete pouring causes a cost increase of TL 54.795,00.

Recommended $2^{\text {nd }}$ Alternative refers to closing the waler beam spacings with a material to be selected and constructing the building external curtains within the correct dimensions. Two different sub-alternatives have been determined by the Value Engineering Team for Alternative 2. 
Alternative $2 \mathrm{a}$ is closing the spaces by a bonding wall. The same function could be fulfilled by a bonding wall instead of undergoing the cost of TL 54.795,00 in the complete concrete pouring and the wall comes to the desired strength during the iron and mold productions which continue after the wall, but it will cause extra shipments for the materials purchased part by part, and fulfillment of this function by bonding wall may cause a loss of time.

Alternative $2 \mathrm{~b}$ refers to making waste mold with profile and $15 \mathrm{~mm}$ OSB2 (oriented strand board). This alternative's advantages: The same function could be fulfilled by bonding wall instead of undergoing the cost of TL 54.795,00 in the complete concrete pouring, the filler material could be purchased as TL $28.500,00$ by forming vertical ground with the profile and with OSB screwing method on it instead of the cost of TL 54.795,00 spent on complete concrete pouring, and the work is completed in less time, but extra shipments may occur if the materials are purchased separately for each floor.

For all three solutions, when value is calculated by the equation:

Value $=\frac{\text { Convenience for Usage (Utility) }}{\text { Cost }}$ it can be seen

that the Alternative $2 \mathrm{~b}$ solution gets the highest value with 0.008566918 . In this case, the optimal solution to the problem would be Alternative $2 b$.

The attained solution has been determined according to the qualifications handled in the study, importance degrees of the qualifications determined by the value engineering team and the selected alternative solutions. Solution to be attained could also change in the event that the alternatives, qualifications and the importance levels and priorities of these qualifications change.

\section{REFERENCES}

[1] Maqbool, R., Sudong, Y., Manzoor, N., \& Rashid, Y. (2017). The impact of emotional intelligence, project managers' competencies, and transformational leadership on project success: An empirical perspective. Project Management Journal, 48(3), 58-75. https://doi.org/10.1177/875697281704800304

[2] Maqbool, R. \& Rashid, Y. (2017). Detrimental changes and construction projects: Need for comprehensive controls. International Journal of Project Organisation and Management, 9(2), 154-170. https://doi.org/10.1504/IJPOM.2017.085291

[3] Mousakhani, E., Yavarkhani, M., \& Sohrabi, S. (2017). Selecting an appropriate alternative for a major infrastructure project with regard to value engineering approach. Journal of Engineering, Design and Technology, 15(3), 395-416. https://doi.org/10.1108/JEDT-12-2015-0083

[4] Li, M. H., Yi, Y. J., \& McFalls, J. (2015). Lifetime cost and performance of slope erosion control products for construction. Geosynthetics International, 16(3), 139-146. https://doi.org/10.1680/gein.2009.16.3.139

[5] Sivakumar Babu, G. L., Rao, R. S., \& Dasaka, S. M. (2015). Stabilisation of vertical cut supporting a retaining wall using soil nailing: a case study. Proceedings of the Institution of Civil Engineers - Ground Improvement, 11(3), 157-162. https://doi.org/10.1680/grim.2007.11.3.157

[6] Katzenbach, R., Leppla, S., Seip, M., \& Kurze Value, S. (2015). Engineering as a basis for safe, optimized and sustainable design of geotechnical structures. Geotechnical Engineering for Infrastructure and Development, 601-606.

[7] Shahhosseini, V., Mohammad, M. R., \& Amiri, O. (2018). Value engineering practices in infrastructure projects: A case study of Ilam Gas Refinery's water transmission system at Reno Mountain, Iran. International Journal of Construction Management, 18(5), 351-363. https://doi.org/10.1080/15623599.2017.1326298

[8] Lee, J. S. (2018). Value engineering for defect prevention on building façade. Journal of Construction Engineering and Management, 144(8). https://doi.org/10.1061/(ASCE)C0.1943-7862.0001500

[9] Khodeir, M. L. \& Ghandour, A. E. (2019). Examining the role of value management in controlling cost overrun (application on residential construction projects in Egypt). Ain Shams Engineering Journal, 10(3), 471-479 https://doi.org/10.1016/j.asej.2018.11.008

[10] Giménez, Z., Mourgues, C., Alarcón, L. F., Mesa, H., \& Pellicer, E. (2020). Value analysis model to support the building design process. Sustainability, 12(10), 1-24. https://doi.org/10.3390/su12104224

[11] Wei, T. \& Chen, Y. (2020). Green building design based on $\mathrm{BIM}$ and value engineering. J. Ambient Intell. Human Comput, 11, 3699-3706. https://doi.org/10.1007/s12652-019-01556-z

[12] Mahmoud, M. H. \& Deab, M. A. (2020). How to reduce carbon dioxide emissions on infrastructure projects in the Middle East. Proceedings of the Institution of Civil Engineers - Civil Engineering, 0(0), 1-40. https://doi.org/10.1680/jcien.20.00051

[13] Dell'Isola, A. J. (1988). Value Engineering in the Construction Industry. Washington, D.C: Smith Hinchman \& Grylls.

[14] Omigbodun, A. (2001). Value engineering and optimal building projects. Journal of Architectural Engineering, $7(2), 40-43$. https://doi.org/10.1061/(ASCE)1076-0431(2001)7:2(40)

[15] Urhan, K. (2004). Value Engineering as a Cost Reduction Tool. Dokuz Eylul University, Institute of Social Sciences, Master Thesis, Izmir, Turkey.

[16] See https://ivm.org.uk/about/history. The Institute of Value Management Website.

[17] Kazanç, D. (2000). Value Engineering in Construction, Istanbul Technical University, Institute of Natural and Applied Sciences, Master Thesis, Istanbul, Turkey.

[18] Tohidi, H. (2011). Review the benefits of using value engineering in information technology project management. Procedia Computer Science, 3, 917-924. https://doi.org/10.1016/j.procs.2010.12.150

[19] Berawi, M. A., Berawi, A. R. B., Prajitno, I. S. P., Nahry, Perdana, M., Yusuf, A., Erwin, T., \& Antonius, I. (2015). Developing conceptual design of high speed railways using value engineering method: Creating optimum project benefit. International Journal of Technology, 4, 670-679. https://doi.org/10.14716/ijtech.v6i4.1743

[20] Behncke, F. G. H., Maisenbacher, S., \& Maurer, M. (2014). Extended model for integrated value engineering. Procedia Computer Science, 28, 781-788. https://doi.org/10.1016/j.procs.2014.03.093

[21] Park, C. S., Kim, H. J., Park, H. T., Goh, J. H., \& Pedro, A. (2017). BIM-based idea bank for managing value engineering ideas. International Journal of Project Management, 35(4), 699-713 https://doi.org/10.1016/j.jproman.2016.09.015

[22] Lee, J. S. (2018). Value engineering for defect prevention on building façade. Journal of Construction Engineering and Management, 144(8), 04018069-1-04018069-8. https://doi.org/10.1061/(ASCE)CO.1943-7862.0001500

[23] Sudiarsa, M., Sudiasa, W., \& Sutapa, K. (2018). Value engineering approach for construction materials selection of 
irrigation drainage. International Journal of Physical Sciences and Engineering, 2(1), 35-46.

https://doi.org/10.29332/ijpse.v2n1.89

[24] Male, S., Kelly, J., Gronqvist, M., \& Graham, D. (2007). Managing value as a management style for projects. International Journal of Project Management, 25(2), 107114. https://doi.org/10.1016/j.jproman.2006.09.001

[25] Mukhopadhyaya, A. K. (2009). Value Engineering Mastermind. India: SAGE Publications.

[26] Fowler, T. C. (1990). Value Analysis Design Competitive Manufacturing Series. USA, New York: John Wiley \& Sons.

[27] Construction and Installation, Rate and Unit Prices. (2018). Ministry of Environment and Urbanization, Turkey.

\section{Contact Information:}

Şenay ATABAY, PhD, Assist. Prof.

(Corresponding author)

Yildiz Technical University,

Department of Civil Engineering,

Construction Management Division,

Davutpasa Campus Esenler, Istanbul, TURKEY

E-mail: satabay@yildiz.edu.tr 